\title{
Azospirillum doebereinerae sp. nov., a nitrogen-fixing bacterium associated with the $\mathrm{C}_{4}$-grass Miscanthus
}

\author{
Barbara Eckert, ${ }^{1}$ Olmar Baller Weber, ${ }^{2}$ Gudrun Kirchhof, ${ }^{1}$ \\ Andras Halbritter, ${ }^{3}$ Marion Stoffels ${ }^{1}$ and Anton Hartmann ${ }^{1}$
}

1 GSF - National Research Centre for Environment and Health, Institute of Soil Ecology, D-85764 Neuherberg, Germany

2 EMBRAPA-CNPAB, Seropédica, CEP 23851-970, Rio de Janeiro, Brazil

3 Department of Microbiology, Eötvös Loránd University, $\mathrm{H}-1088$ Múzeum körút 4/A, Budapest, Hungary
Author for correspondence: Anton Hartmann. Tel: +49 893187 4109. Fax: +49 8931873376. e-mail: hartmann@gsf.de

A new group of nitrogen-fixing Azospirillum sp. bacteria was isolated from the roots of the $\mathrm{C}_{4}$-gramineous plant Miscanthus. Polyphasic taxonomy was performed, including auxanography using API galleries, physiological tests and 165 rRNA sequence comparison. The ability of the isolates to fix dinitrogen was evaluated by amplification of the nifD gene, immunodetection of the dinitrogenase reductase and acetylene-reduction assay. On the basis of these results, the nitrogen-fixing isolates represent a new species within the genus Azospirillum. Its closest phylogenetic neighbours, as deduced by 165 rDNAbased analysis, are Azospirillum lipoferum, Azospirillum largimobile and Azospirillum brasilense with $96 \cdot 6,96.6$ and $95.9 \%$ sequence similarity, respectively. Two 16S rRNA-targeting oligonucleotide probes were developed which differentiate the new species from the other Azospirillum species by whole-cell fluorescence hybridization. Strains of the new species are curved rods or S-shaped, 1.0-1.5 $\mu \mathrm{m}$ in width and 2.0-30 $\mu \mathrm{m}$ in length, Gram-negative and motile with a single polar flagellum. Optimum growth occurs at $30^{\circ} \mathrm{C}$ and at pH values between 6.0 and 7.0. No growth takes place at $37^{\circ} \mathrm{C}$. They have a respiratory type of metabolism, grow well on arabinose, D-fructose, gluconate, glucose, glycerol, malate, mannitol and sorbitol. They differ from $A$.

largimobile and $\boldsymbol{A}$. lipoferum by their inability to use $\boldsymbol{N}$-acetylglucosamine and D-ribose, from $A$. lipoferum by their ability to grow without biotin supplementation and from $A$. brasilense by their growth with D-mannitol and $D$-sorbitol as sole carbon sources. Nitrogen fixation occurs in microaerobic nitrogen-limited conditions. For this species, the name Azospirillum doebereinerae sp. nov. is suggested, with strain GSF71' as the type strain (= DSM 13131'; reference strain Ma4 = DSM 13400). Its $\mathrm{G}+\mathrm{C}$ content is $70.7 \mathrm{~mol} \%$.

Keywords: Azospirillum, Miscanthus, plant-associated bacteria, diazotroph

\section{INTRODUCTION}

Since the first detailed description of the genus Azospirillum with two species, Azospirillum lipoferum and Azospirillum brasilense (Tarrand et al., 1978), members of Azospirillum has been isolated from the roots of numerous wild and cultivated grasses, cereals,

The EMBL accession numbers for the partial 16S rDNA sequence and the partial nifD sequence of Azospirillum doebereinerae sp. nov. are AJ238567 and AJ238568, respectively. food crops and soils from tropical, subtropical and temperate regions all over the world (Döbereiner et al., 1976; Bally et al., 1983; Ladha et al., 1987; Kirchhof et al., 1997a; Gunarto et al., 1999). Semi-solid nitrogenfree medium (Döbereiner, 1980) was the key to the successful isolation of microaerophilic $\mathrm{N}_{2}$-fixing bacteria. Using this technique, it was possible to isolate and describe three more species: Azospirillum amazonense (Magalhães et al., 1983), Azospirillum halopraeferens (Reinhold et al., 1987) and Azospirillum irakense (Khammas et al., 1989). On the basis of $16 \mathrm{~S}$ rDNA and DNA-DNA hybridization studies, the 
former Conglomeromonas largomobilis subsp. largomobilis (Skerman et al., 1983) was recently transferred to the genus Azospirillum as Azospirillum largomobile (Ben Dekhil et al., 1997) and subsequently the name was corrected to Azospirillum largimobile by Sly \& Stackebrandt (1999).

It is generally accepted that members of the genus Azospirillum can enhance the growth of plants in different modes, triggered, for example, by the production of phytohormones, which are signal molecules that interfere with plant metabolism (Bashan \& Holguin, 1997). It is also possible that these bacteria transfer nitrogen to their host plants (Döbereiner, 1983; Okon, 1985). Although the $\mathrm{N}_{2}$-fixation in planta has not yet been shown unequivocally in azospirilla, the contribution of biological fixed nitrogen to the total plant nitrogen uptake is estimated as being between 40 and $80 \%$ in some varieties of sugar cane (Boddey et al., 1995; Yoneyama et al., 1997). In sorghum (Giller et al., 1986), maize (Boddey, 1987) and rice (Baldani et al., 1995), the range was 0-30\% depending on the cultivar tested.

Miscanthus is a perennial lignocellulose-producing grass and a possible alternative crop for farmers using fields taken out of grain-crop production. Originally grown in southeastern Asia, Miscanthus can be established and cultivated under European temperate climatic conditions (Hartley, 1958). The plant fibre is utilized for the production of paper pulp or for replacing fossil energy in biomass power stations. Miscanthus is characterized by its highly efficient photosynthesis, like Zea mays and Saccharum notatum, which use $\mathrm{a}_{4}$ type of photosynthate carbon assimilation involving oxaloacetate and the Calvin cycle. In these plants, wasteful photorespiration is absent and therefore rates of photosynthesis and plant production are higher. In various field experiments, it has been demonstrated that the biomass yield (20-30 tons per hectare per year) does not increase with the application of mineral nitrogen fertilizer (Schwarz et al., 1994). Christian et al. (1997) analysed the nitrogen balance of Miscanthus in ${ }^{15} \mathrm{~N}$-amended soil. In 2 years, the nitrogen uptake of the plant was greater than the amount supplied as fertilizer and as soil nitrogen sources, indicating that the plant was able to obtain substantial amounts of nitrogen from other sources.

The lack of response to nitrogen fertilization, combined with high biomass production, suggested that biological nitrogen fixation may be involved and that diazotrophic bacteria could be associated with this plant. The use of specific enrichment procedures and oligonucleotide probes made it possible to isolate and characterize various diazotrophic bacteria from Miscanthus plant tissues (Kirchhof et al., 1997a, b). After physiological and phylogenetical analyses, most of these isolates were assigned to the genus Herbaspirillum, in which they constitute a new species (Kirchhof et al., 2001), and the genus Azospirillum.
In this report, we present the phylogenetic position and physiological properties of a new species, for which the name Azospirillum doebereinerae is proposed, and two species-specific oligonucleotide probes for the identification and detection of this new species by in situ fluorescence hybridization.

\section{METHODS}

Isolation. All of the strains used in this study are listed in Table 1. Roots of Miscanthus sinensis cv. 'Giganteus' and rhizosphere soil were collected from fields, on which there had been continuous Miscanthus cultivation since 1990, at the LBP (Bayerische Landesanstalt für Bodenkultur und Pflanzenbau), Freising, Germany. The roots were washed with sterile water and then crushed in $4 \%$ sucrose solution by using a mortar and pestle. Small vessels (approx. $10 \mathrm{ml}$ ) containing $5 \mathrm{ml} \mathrm{NFb}$ semi-solid nitrogen-free medium (Döbereiner, 1995) were inoculated with serial dilutions of crushed roots or rhizosphere soil suspensions. The composition of the $\mathrm{NFb}$ medium is as follows $\left(1^{-1}\right)$ : malate $(5.0 \mathrm{~g}) ; \mathrm{K}_{2} \mathrm{HPO}_{4}(0.5 \mathrm{~g}) ; \mathrm{MgSO}_{4} .7 \mathrm{H}_{2} \mathrm{O}(0.2 \mathrm{~g}) ; \mathrm{NaCl}(0 \cdot 1 \mathrm{~g})$; $\mathrm{CaCl}_{2} .2 \mathrm{H}_{2} \mathrm{O}(0.02 \mathrm{~g})$; bromothymol blue $0.5 \%$ in $\mathrm{KOH} 0.2$ M (2 $\mathrm{ml})$; sterile, filtered vitamin solution $(1 \mathrm{ml})$; sterile, filtered micronutrient solution $(2 \mathrm{ml}) ; 1.64 \%$ FeEDTA solution $(4 \mathrm{ml})$; $\mathrm{KOH}(4.5 \mathrm{~g})$. The $\mathrm{pH}$ was adjusted to 6.5 and $1.8 \mathrm{~g}$ agar $1^{-1}$ was added. The vitamin solution contains, in $100 \mathrm{ml}$, biotin $(10 \mathrm{mg})$ and pyridoxol- $\mathrm{HCl}$ $(20 \mathrm{mg})$, dissolved at $100^{\circ} \mathrm{C}$ in a water bath. The micronutrient solution consists of the following $\left(1^{-1}\right)$ : $\mathrm{CuSO}_{4} \cdot 5 \mathrm{H}_{2} \mathrm{O}(40 \mathrm{mg}) ; \mathrm{ZnSO}_{4} \cdot 7 \mathrm{H}_{2} \mathrm{O}(0 \cdot 12 \mathrm{~g}) ; \mathrm{H}_{2} \mathrm{BO}_{3}$ $(1.4 \mathrm{~g}) ; \mathrm{Na}_{2} \mathrm{MoO}_{4} \cdot 2 \mathrm{H}_{2} \mathrm{O}(1 \cdot 0 \mathrm{~g}) ; \mathrm{MnSO}_{4} \cdot \mathrm{H}_{2} \mathrm{O}(1 \cdot 175 \mathrm{~g})$. $\mathrm{JNFb}$ contains extra $\mathrm{K}_{2} \mathrm{HPO}_{4}(0 \cdot 6 \mathrm{~g})$ and $\mathrm{KH}_{2} \mathrm{PO}_{4}(1 \cdot 8 \mathrm{~g})$ to stabilize the $\mathrm{pH}$ at about $5 \cdot 8$.

After 3-5 dincubation at $30^{\circ} \mathrm{C}$, one loop of pellicle-forming culture was transferred into fresh semi-solid medium. Further purification was done on NFb (supplemented with $50 \mathrm{mg}$ yeast extract $\mathrm{l}^{-1}$ ) and half-strength DYGS medium (modified from that described by Rodrigues Neto et al., 1986) agar plates. Pellicle forming cultures were maintained on half-strength DYGS medium containing the following $\left(1^{-1}\right)$ : glucose $(1.0 \mathrm{~g})$; malate $(1.0 \mathrm{~g})$; yeast extract $(2.0 \mathrm{~g})$; peptone $(1.5 \mathrm{~g}) ; \mathrm{MgSO}_{4} .7 \mathrm{H}_{2} \mathrm{O}(0.5 \mathrm{~g}) ;$ L-glutamic acid $(1.5 \mathrm{~g})$. The $\mathrm{pH}$ was adjusted to $6 \cdot 0$.

Morphological examination. Morphology and Gram-type were determined by using an Axioplan phase-contrast microscope (Zeiss). The type of flagellation and the cell dimensions were determined by electron microscopy using preparations negatively stained for $30 \mathrm{~min}$ with uranyl acetate (Ultrostain 1; Leica) or for 4 min with lead citrate (Ultrostain; Leica).

Phenotypic characterization. Carbon-source utilization was tested by using the API50 CHE and API20 NE gallery methods (bioMérieux). Cells from liquid overnight cultures in half-strength DYGS medium were harvested and washed twice with sterile PBS. The bacterial inoculum was diluted in minimal medium, according to the manufacturer's instructions, incubated aerobically at $30^{\circ} \mathrm{C}$ and examined visually for growth daily over a period of $5 \mathrm{~d}$. Additionally, the API50 CHE gallery method was performed anaerobically and acid production was recorded.

Furthermore, pellicle-forming ability and microaerobic $\mathrm{N}_{2}{ }^{-}$ dependent growth were assessed in semi-solid JNFb medium 
Table 1. Origins of the bacterial strains used in this study

\begin{tabular}{|c|c|c|c|}
\hline Strain* & Source $\dagger$ & Reference & Origin \\
\hline Azospirillum sp. GSF21 & GSF/ISE & Kirchhof et al. (1997a) & Washed roots of Miscanthus sacchariflorus \\
\hline Azospirillum sp. GSF65 & This report & & Washed roots of Miscanthus sinensis cv. 'Giganteus' \\
\hline Azospirillum sp. GSF66 & This report & & Washed roots of Miscanthus sinensis cv. 'Giganteus' \\
\hline Azospirillum sp. GSF67 & This report & & Washed roots of Miscanthus sinensis cv. 'Giganteus' \\
\hline Azospirillum sp. GSF68 & This report & & Washed roots of Miscanthus sinensis cv. 'Giganteus' \\
\hline Azospirillum sp. GSF69 & This report & & Washed roots of Miscanthus sinensis cv. 'Giganteus' \\
\hline Azospirillum sp. GSF70 & This report & & Washed roots of Miscanthus sinensis cv. 'Giganteus' \\
\hline Azospirillum sp. GSF71 ${ }^{\mathrm{T}}$ & This report & & Washed roots of Miscanthus sinensis cv. 'Giganteus' \\
\hline Azospirillum sp. GSF76 & This report & & Rhizosphere soil (Miscanthus sinensis) \\
\hline Azospirillum sp. GSFe & This report & & Rhizosphere soil (Miscanthus sinensis) \\
\hline Azospirillum sp. Ma4 & This report & & Washed roots of Miscanthus sinensis cv. 'Giganteus' \\
\hline Azospirillum lipoferum GSF1 & GSF/ISE & Kirchhof et al. (1997a) & Washed roots of Spartina pectinata \\
\hline Azospirillum lipoferum GSF5 & GSF/ISE & Kirchhof et al. (1997a) & Washed roots of Spartina pectinata \\
\hline Azospirillum lipoferum GSF15 & GSF/ISE & Kirchhof et al. (1997a) & Washed roots of Spartina pectinata \\
\hline Azospirillum lipoferum GSF18 & GSF/ISE & Kirchhof et al. (1997a) & Washed stem of Miscanthus sinensis cv. 'Giganteus' \\
\hline Azospirillum lipoferum GSF26 & GSF/ISE & Kirchhof et al. (1997a) & Washed roots of Miscanthus sacchariflorus \\
\hline Azospirillum lipoferum $\mathrm{SpA} 3 \mathrm{a}$ & DSM 1838 & Tarrand et al. (1978) & Grass roots \\
\hline Azospirillum lipoferum $\mathrm{Sp} 59 \mathrm{~b}$ & DSM $1691^{\mathrm{T}}$ & Tarrand et al. (1978) & Wheat roots \\
\hline Azospirillum lipoferum SpRG6 & DSM 1841 & Tarrand et al. (1978) & Wheat roots \\
\hline Azospirillum lipoferum $\mathrm{SpRG} 20 \mathrm{a}$ & DSM 1840 & Tarrand et al. (1978) & Wheat roots \\
\hline Azospirillum largimobile & ACM $2041^{\mathrm{T}}$ & Skerman et al. (1983) & Fresh water \\
\hline Azospirillum brasilense Wa 3 & C. Christiansen-Weniger & Christiansen-Weniger \& van Ven (1991) & Rhizosphere of wheat \\
\hline Azospirillum brasilense $\mathrm{Sp} 7$ & DSM $1690^{\mathrm{T}}$ & Tarrand et al. (1978) & Digitaria decumbens roots \\
\hline Azospirillum brasilense $\mathrm{Cd}$ & DSM 1843 & Tarrand et al. (1978) & Cynodon dactylon roots \\
\hline Azospirillum brasilense JM 6A2 & DSM 1858 & Tarrand et al. (1978) & Maize roots \\
\hline Azospirillum amazonense Y-1 & DSM $2787^{\mathrm{T}}$ & Magalhães et al. (1983) & Digitaria decumbens roots \\
\hline Azospirillum amazonense Y-6 & DSM 2789 & Magalhães et al. (1983) & Pennisetum purpureum roots \\
\hline Azospirillum irakense $\mathrm{KBC1}$ & DSM $11586^{\mathrm{T}}$ & Khammas et al. (1989) & Rice roots \\
\hline Azospirillum halopraeferens AU4 & DSM $3675^{\mathrm{T}}$ & Reinhold et al. (1987) & Leptochloa fusca, root \\
\hline Azospirillum sp. $4 \mathrm{AZ}$ & DSM 4834 & Malik (1988) & Fresh water \\
\hline Azospirillum sp. $5 \mathrm{AZ}$ & DSM 4835 & Malik (1988) & Fresh water \\
\hline Azospirillum sp. & DSM 1726 & Malik \& Schlegel (1980) & Plant litter \\
\hline Azospirillum sp. & DSM 1727 & Malik \& Schlegel (1980) & Plant litter \\
\hline Skermanella parooensis & ACM $2042^{\mathrm{T}}$ & Skerman et al. (1983) & Fresh water \\
\hline Rhodospirillum centenaria & DSM $9894^{\mathrm{T}}$ & Favinger et al. (1989) & Hot spring \\
\hline
\end{tabular}

* All Azospirillum sp. isolates were obtained from fields of Miscanthus at the Bayerische Landesanstalt für Bodenkultur und Pflanzenbau (LBP), Freising, Germany.

$\dagger$ DSM, Deutsche Sammlung von Mikroorganismen und Zellkulturen (DSMZ), Braunschweig, Germany; ACM, Australian Collection of Microorganisms, Department of Microbiology, The University of Queensland, St Lucia, Australia; GSF/ISE, GSFInstitute of Soil Ecology, Neuherberg/Munich, Germany.

with different carbon sources. For this purpose, malate was replaced by fructose, glucose, glycerol, myo-inositol, maltose, D-mannitol, D-ribose, D-sorbitol or sucrose (Döbereiner, 1995). Three replicates were inoculated with $10 \mu \mathrm{l}$ washed overnight culture in half-strength DYGS and incubated over a period of $3-4 \mathrm{~d}$ at $30{ }^{\circ} \mathrm{C}$. To test the ability of the cells to grow with $\mathrm{NaCl}, 3 \% \mathrm{NaCl}$ was added to semi-solid $\mathrm{NFb}$ medium.

The oxidase test was performed with Bactident-Oxidase test strips (Merck). Analyses for urease activity (API20 NE) and the biotin requirement (Tarrand et al., 1978) were carried out as described in the literature.

The influences of temperature and $\mathrm{pH}$ on bacterial growth were analysed by measuring the optical density at $436 \mathrm{~nm}$ in liquid half-strength DYGS or minimal medium for Azospirillum (Tarrand et al., 1978), respectively, with shaking at 150 r.p.m. The test for scarlet coloration of colonies on Congo red medium was performed as described by Caceres (1982).

Phylogenetic analysis. Approximately $1300 \mathrm{bp}$ of the $16 \mathrm{~S}$ rDNA of strain GSF71 ${ }^{\mathrm{T}}$ was amplified by a PCR with primers 63f and 1387r (Marchesi et al., 1998). The purified product was sequenced by Eurogentec by using the ABI
PRISM Dye Terminator Cycle Sequencing Ready Reaction Kits (Applied Biosystems). The new sequence was added to an alignment of approximately 6000 published homologous sequences from bacteria, using the alignment tool of the software package ARB (O. Strunk \& W. Ludwig; http:// www.mikro.biologie.tu-muenchen.de/pub/ARB/). Phylogenetic analyses were performed by applying distancematrix (ARB; Felsenstein, Jukes-Cantor), maximumparsimony (ARB) and maximum-likelihood methods (fastDNAml; Maidak et al., 1994) as described previously (Wittke et al., 1997). The data sets used for the calculations varied with respect to the reference sequences and with respect to the alignment positions included. These alternative treeing methods generated locally differing trees and the consensus tree was constructed using the results of different methods.

Oligonucleotide probes. On the basis of the $16 \mathrm{~S}$ rDNA sequence, new specific probes for in situ hybridization were designed using the PROBE DESIGN tool of the software package ARB. Oligonucleotide probes labelled with the fluorescent dyes $\mathrm{Cy} 3$ and FLUOS were purchased from Interactiva.

Cell fixation. Cells from exponentially growing cultures were fixed with $4 \%(\mathrm{w} / \mathrm{v})$ paraformaldehyde according to Amann et al. (1990). Cell suspensions were immobilized on micro- 
scope slides by air-drying. The cells were further fixed and dehydrated by immersing the slides in 50, 80 and $96 \%$ ethanol (Amann et al., 1995).

In situ hybridization and microscopy. In situ whole-cell hybridization was performed as described by Snaidr et al. (1997). Slides were examined with an Axioplan microscope (Zeiss) using filter sets 09 and 15.

Probe evaluation. In situ hybridization conditions for the new oligonucleotide probes were optimized by gradually increasing the formamide concentration in the hybridization solution as described by Manz et al. (1992).

$\mathbf{G}+\mathbf{C}$ content. The mean $\mathrm{G}+\mathrm{C}$ content $(\mathrm{mol} \%)$ of the DNA of the new bacterial isolates was determined by using the thermal denaturation method (Johnson, 1989). The melting profiles were recorded photometrically with a programmable thermophotometer (Gilford 250) and the $\mathrm{G}+\mathrm{C}$ content $(\mathrm{mol} \%)$ was calculated using the equation of Owen \& Lapage (1976).

Estimation of nitrogen-fixing ability using nifD PCRamplification. Bacterial isolates were analysed for the presence of the nifD gene by using a PCR approach with universal nifD primers (Stoltzfus et al., 1997). The reaction products were separated by agarose gel electrophoresis, stained with ethidium bromide and the band size calculated by comparison with the $100 \mathrm{bp}$ ladder length standard (Gibco-BRL). Finally, the purified nifD-PCR product was subjected to direct sequencing by TOPLAB (Martinsried, Germany). The resulting sequence was compared with sequences in the EMBL database.

Immunological detection of dinitrogenase reductase. The presence of nitrogenase was detected by SDS-PAGE and Western blot analyses with a polyclonal antiserum directed to the dinitrogenase reductase of Rhodospirillum rubrum and Azotobacter vinelandii (a kind gift from P. W. Ludden, University of Wisconsin, Madison, USA). This antiserum was purified with a protein A column (Bio-Rad). Cells were grown either for $3 \mathrm{~d}$ in semi-solid nitrogen-free NFb medium or overnight in liquid half-strength DYGS medium supplemented with $10 \mathrm{mM} \mathrm{NH} \mathrm{m}_{4} \mathrm{Cl}$, then harvested and washed with sterile PBS. The protein content was determined by the method of Harlow \& Lane (1988). A quantity of bacteria, representing $1.5 \mu \mathrm{g}$ total protein, was boiled for $10 \mathrm{~min}$ in SDS-PAGE sample buffer (Qiagen) and the proteins were separated by SDS-PAGE according to the method of Laemmli (1970). Electroelution on nitrocellulose sheets (Hybond ECL; Amersham) was carried out with a semi-dry electroblotter (Bio-Rad). The immunological detection was performed according to Schloter et al. (1995).

Acetylene-reduction assay. The ability to fix nitrogen was tested by using the acetylene-reduction assay. For this purpose, bacterial cultures were grown in five vials of $15 \mathrm{ml}$ volumes of semi-solid $\mathrm{NFb}$ medium and the $23 \mathrm{ml}$ vials were sealed with rubber septa; $36 \mathrm{~h}$ after the inoculation, a 1/10 volume (air volume) of acetylene was added (Burris, 1972). The amount of ethylene was measured every $30 \mathrm{~min}$ for a total of $4 \mathrm{~h}$. All incubations were done at $30^{\circ} \mathrm{C}$ in the dark, avoiding any movement of the vials. Ethylene was measured using a Hewlett Packard 5890A gas chromatograph equipped with a flame-ionization detector and a packed column $(1.83 \mathrm{~m}$ long, $0.318 \mathrm{~cm}$ i.d., stainless steel, packed with HayeSep N; Supelco). Calculations were based on peak area. The software CHEMSTATION (Hewlett Packard) was used for data analysis. To determine the cell number, serial dilutions of the culture were performed at the end of the incubation, plated on half-strength DYGS medium and then counted after incubation at $30^{\circ} \mathrm{C}$ for $5 \mathrm{~d}$.

\section{RESULTS AND DISCUSSION}

\section{Phylogenetic relationship}

The $16 \mathrm{~S}$ rRNA sequence analysis of $A$. doebereinerae sp. nov. GSF $71^{\mathrm{T}}$ revealed that it is a member of the $\alpha$ subclass of the Proteobacteria, clustering with other Azospirillum species. The species $A$. lipoferum, $A$. largimobile, A. brasilense and $A$. halopraeferens showed the highest $16 \mathrm{~S}$ rDNA sequence similarity with $A$. doebereinerae strain GSF71 ${ }^{\mathrm{T}}$, i.e. $96 \cdot 6,96 \cdot 6,95 \cdot 9$ and $93.6 \%$, respectively. $A$. irakense and $A$. amazonense showed 90.6 and $90.2 \% 16 \mathrm{~S}$ rDNA sequence similarity. The phylogenetic position of strain $\mathrm{GSF} 71^{\mathrm{T}}$ within the genus Azospirillum is shown in Fig. 1. The phylogenetic tree is based on a combination of the results of three treeing methods, namely maximumlikelihood, maximum-parsimony and distance-matrix analyses of $50 \alpha$-proteobacterial 16S rDNA sequences. This approach was used to enable estimation of the robustness of the tree topology. It indicates that $A$. lipoferum and $A$. largimobile are the closest relatives of A. doebereinerae GSF71 ${ }^{\mathrm{T}}$. A. brasilense also shows a high level of sequence similarity, but the branches clearly separate. These results were confirmed by maximum-parsimony and maximum-likelihood analyses. The exact branching order of strain GSF $71^{\mathrm{T}}$ with respect to its nearest neighbours ( $A$. largimobile and $A$. lipoferum) in the phylogenetic tree could not be determined unambiguously, because it changed according to different tree calculation methods and different alignment positions. Therefore the branches of these three species were arbitrarily shifted in such a way that they originate in one multifurcation. The DNA G + C content of strain GSF $71^{\mathrm{T}}$ is $70.7 \mathrm{~mol} \%$, which is in accordance with the values for the genus Azospirillum (64-71 mol \%; Ben Dekhil et al., 1997).

\section{Design and optimization of oligonucleotide probes specific for $\boldsymbol{A}$. doebereinerae isolates}

On the basis of the use of the PROBE DESIGN tool of the software package ARB, two new probes (Adoeb94 and Adoeb587) specific for the new Azospirillum sp. isolates were designed. Both probes are targeted to the $16 \mathrm{~S}$ rRNA. The Adoeb587 probe has the sequence 5'ACTTCCGACTAAACAGGC-3' at positions 587604 and the Adoeb94 probe has the sequence $\left(5^{\prime}-3^{\prime}\right) 5^{\prime}-$ CGTGCGCCACTGTGCCGA-3' at positions 94-111 (according to Escherichia coli numbering of the $16 \mathrm{~S}$ rDNA sequence; Brosius et al., 1981). Optimal hybridization conditions were evaluated by in situ whole-cell hybridization of reference cells with fluorescently labelled oligonucleotide probes. The formamide concentration of $30 \%(\mathrm{v} / \mathrm{v})$ in the standard hybridization solution at $46^{\circ} \mathrm{C}$ is recommended for both probes, because this is the highest concentration 


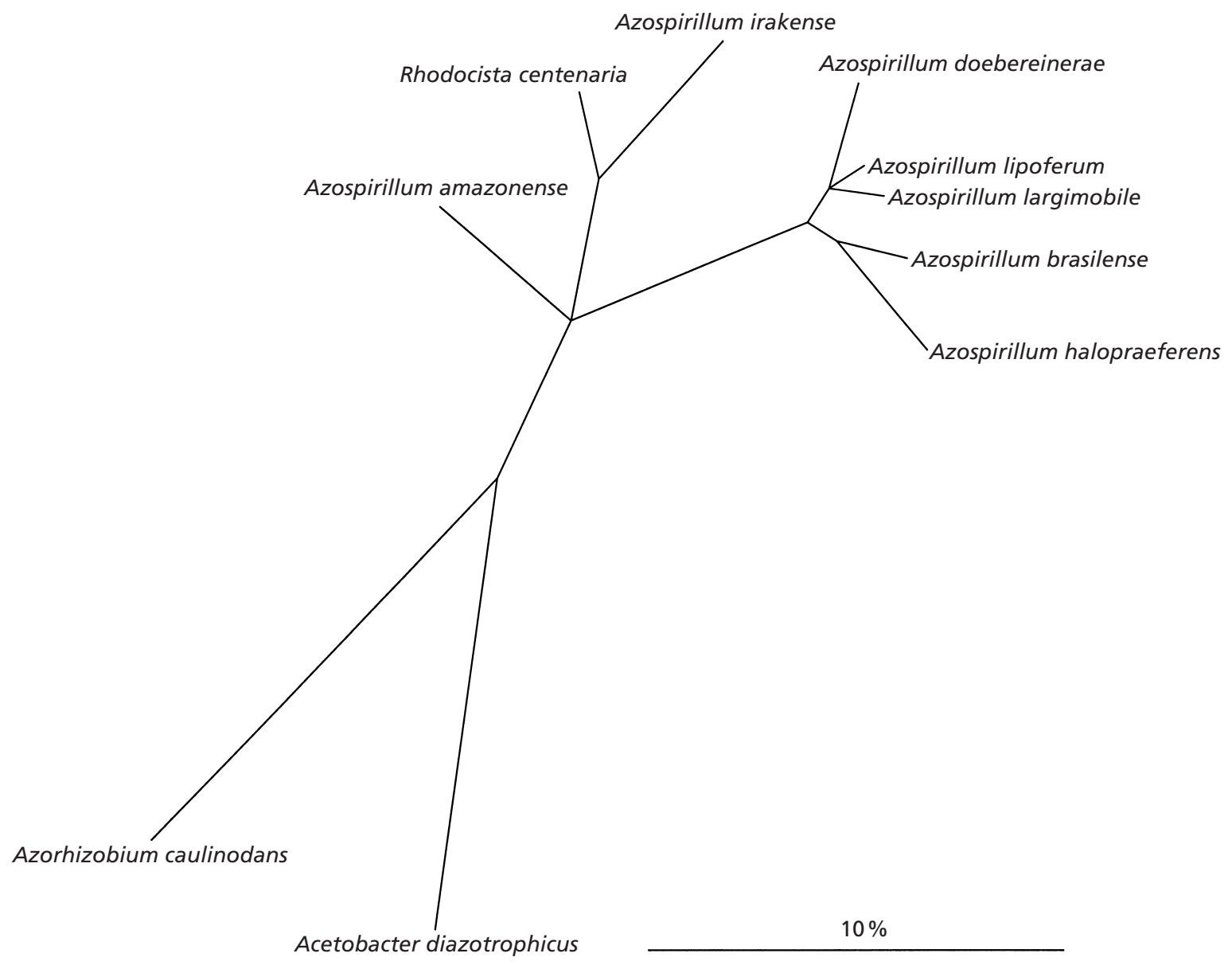

Fig. 1. Phylogenetic relationship between strain GSF71 ${ }^{\top}$ and other Azospirillum species and selected representatives of the $\alpha$-subclass of the Proteobacteria, based on the results of a maximum-likelihood analysis of nearly complete 16S rRNA sequences. Only sequence positions that share common residues in at least $50 \%$ of the members of the $\alpha$-Proteobacteria were included for the calculation of this tree. The tree topology was evaluated and corrected according to the results of distance and maximum-parsimony analysis. Multifurcations indicate branches for which a relative order of the branching cannot be determined unambiguously or for which a common order is not supported when different treeing methods are applied. For the sake of clarity, only a selection of the reference sequences is shown. Bar, $10 \%$ estimated base changes. Strain and accession numbers of the species shown in this tree: $A$. amazonense DSM $2787^{\top}, Z_{229616 ;}$. centenaria, IAM 14193' ${ }^{\top}$, D12701; A. irakense DSM 11586 ${ }^{\top}, \mathrm{Z}^{2} 9583 ;$ A. doebereinerae DSM 13131 ${ }^{\top}$, AJ238567; A. lipoferum ATCC 29707, M59061; A. largimobile ACM 2041 ${ }^{\top}$, X90759; A. brasilense ATCC 29145 ${ }^{\top}$ X79739; A. halopraeferens DSM $3675^{\top}, \mathrm{X} 79731$; A. caulinodans, LMG $6465^{\top}, \mathrm{X} 67221$; A. diazotrophicus ATCC $49037^{\top}, \mathrm{X} 75618$.

that still yielded good hybridization signals with the target cells and additionally allowed a discrimination of non-target cells. Oligonucleotide Adoeb587 has only a single destabilizing $\mathrm{C}-\mathrm{A}$ mismatch at probe position $6\left(5^{\prime}-3^{\prime}\right)$ in the target sequences of two $A$. lipoferum strains (DSM 1840 and DSM 1841) and $A$. largimobile. The binding of probe Adoeb587 to the 16S rDNA of these bacteria could be completely prevented by the addition of $30 \%$ formamide to the hybridization solution. Oligonucleotide Adoeb94 has at least two mismatches with respect to all other known 16S rDNA sequences and also shows bright and specific hybridization signals with a formamide concentration of $30 \%$ in the hybridization solution. The two new probes, together with probe EUB338, which is specific for all Eubacteria (Amann et al., 1990), were suc- cessfully used for a fast, whole-cell, in situ characterization of bacterial isolates. All strains, except the new ones belonging to $A$. doebereinerae sp. nov. (GSF21, GSF65, GSF66, GSF67, GSF68, GSF69, GSF70, GSF71 ${ }^{\mathrm{T}}$, GSF76, GSFe, Ma4), were negative for hybridization with Adoeb94 or Adoeb587, and all strains were positive for hybridization with EUB338. After screening of nearly all of the Azospirillum isolates from Miscanthus (Kirchhof et al., 1997a), it was found that a single previous isolate, GSF21, from Miscanthus sacchariflorus, could also be assigned to the new group. This affiliation could be confirmed by carbonutilization pattern analysis. The combined application of both probes offers the possibility for in situ identification of this new group of Azospirillum strains in environmental samples. Combined application of 

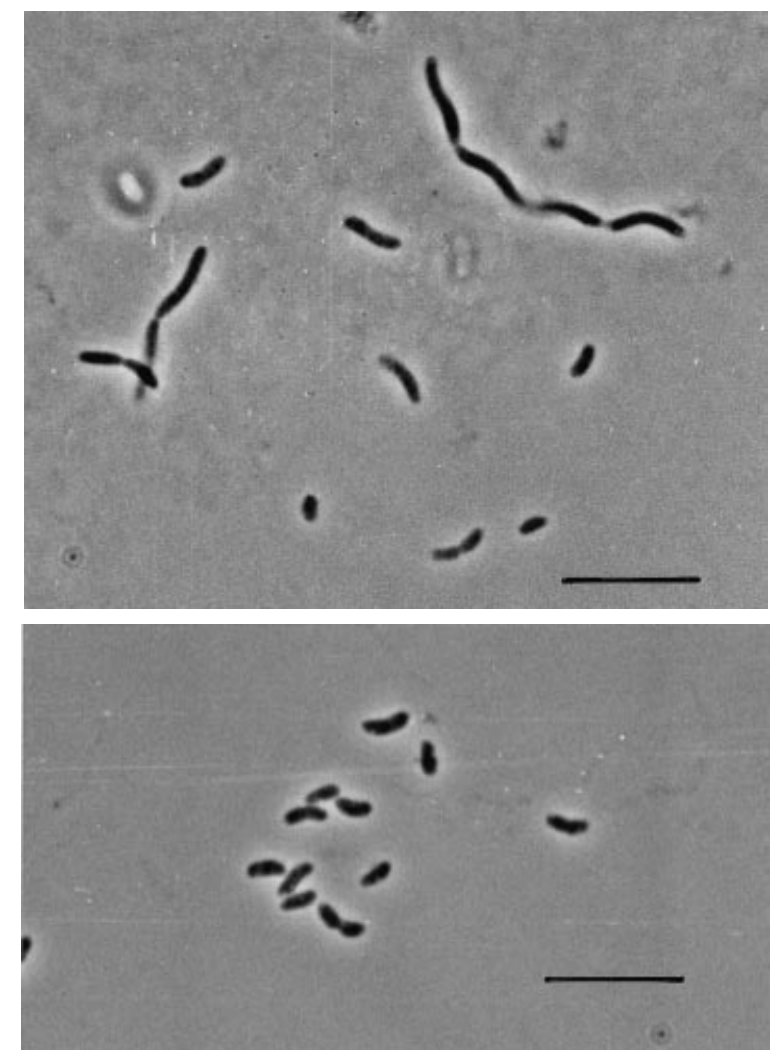

Fig. 2. (top) Micrograph of pleomorphic cells of $A$. doebereinerae sp. nov. strain GSF71 ${ }^{\top}$ grown for $5 \mathrm{~d}$ in semi-solid $\mathrm{NFb}$ medium. (bottom) Micrograph of uniform small cells of $A$. doebereinerae sp. nov. strain GSF71 ${ }^{\top}$ grown in half-strength DYGS-medium liquid culture overnight. Bar, $10 \mu \mathrm{m}$.

both probes with the same specificity ensures reliable identification of the species by double staining.

\section{Cell morphology and growth characteristics}

Cells of $A$. doebereinerae sp. nov. isolates are curved rods or S-shaped, $1 \cdot 0-1.5 \mu \mathrm{m}$ wide and $2 \cdot 0-30 \mu \mathrm{m}$ long. After growth overnight in liquid medium cells are small and vibroid (Fig. 2, bottom), whereas after prolonged growth in semi-solid $\mathrm{N}$-free $\mathrm{Nfb}$ medium the cells are long and pleomorphic (Fig. 2, top). Accordingly, the movement of these Gram-negative cells is winding or snake-like. A single polar flagellum was observed when cells were grown in liquid medium. Ageing cells contained intracellular granules (probably poly- $\beta$-hydroxybutyrate). Cells were not encapsulated at the conditions tested. On NFb agar plates supplemented with $20 \mathrm{mg}$ yeast extract and triple-strength bromothymol blue, the colonies were $0.5 \mathrm{~mm}$ in diameter and appeared grey and dull. On half-strength DYGS agar plates, the bacteria formed small adhesive colonies. Colonies grown on Congo red medium were scarlet. In semi-solid nitrogen-free malate medium, they formed a veil-like pellicle that first developed several millimetres below the medium surface and later moved close to the surface.

\section{Phenotypic features}

The new Azospirillum sp. isolates were chemoorganoheterotrophic and exhibited a respiratory type of metabolism with oxygen as the terminal electron acceptor. Nitrate could be used for denitrification. $\mathrm{N}_{2}$ could be fixed at microaerobic conditions. Oxidase and urease tests were positive. Biotin was not required for growth. The optimum temperature for growth was tested at $25,30,37$ and $42{ }^{\circ} \mathrm{C}$. The best growth was observed at $30{ }^{\circ} \mathrm{C}$ and no growth occurred at 37 or $42{ }^{\circ} \mathrm{C}$. Of the range of $\mathrm{pH}$ values tested $(3 \cdot 0-10 \cdot 5)$, the best growth occurred at $\mathrm{pH} 6 \cdot 0-7 \cdot 0$. Growth did not occur in the presence of $3 \% \mathrm{NaCl}$. Aesculin was hydrolysed.

The API20 NE system showed that arabinose, gluconate, malate and mannitol were utilized in 1-3 d by $90-100 \%$ of the tested strains. The tests for $\beta$ glucosidase, urease and $\beta$-galactosidase were positive. The API50 CHE test performed under aerobic cultivation showed that glycerol, D-mannitol, D-sorbitol, D-fructose and aesculin were positive for more than $90 \%$ of the tested strains within 1-6 d incubation. When tested with the remaining substrates in the API $20 \mathrm{NE}$ and API50 CHE tests, after $6 \mathrm{~d}$ more than $90 \%$ of the strains tested failed to utilize the following as sole sources of carbon and energy: adonitol, $\mathrm{N}$ acetylglucosamine, starch, amygdalin, D-arabinose, D-arabitol, L-arabitol, arbutin, caprate, cellobiose, 5keto-glucanate, 2-keto-gluconate, citrate, dulcitol, erythritol, L-fructose, $\beta$-gentiobiose, glycogen, inositol, inulin, lactose, D-lyxose, maltose, mannose, Dmannose, melezitose, melibiose, methyl $\alpha$-D-glucoside, methyl $\alpha$-D-mannoside, methyl $\beta$-xyloside, phenylacetate, D-raffinose, rhamnose, ribose, saccharose, salicine, L-sorbose, D-tagatose, trehalose, D-turanose, xylitol, D-xylose and L-xylose. Occasional and varying growth occurred after $6 \mathrm{~d}$ on adipate, galactose, Dglucose and gluconate. Microaerobic $\mathrm{N}_{2}$-fixing-dependent growth was observed with the carbon sources malate, sorbitol, mannitol and glycerol. No growth occurred with maltose, sucrose, ribose or inositol. Growth with glucose in semi-solid nitrogen-free media was not uniform. With fructose as the substrate, the pellicles were very weak. A summary of the results of carbon-source utilization suitable for the differentiation of $A$. doebereinerae sp. nov. from the known Azospirillum species is presented in Table 2.

\section{Nitrogen-fixing ability}

All Azospirillum sp. strains were isolated from the roots of Miscanthus by using semi-solid nitrogen-free media. They did not lose the capacity to grow with $\mathrm{N}_{2}$ under microaerobic conditions, even after repeated transfers on complex media. The $\mathrm{N}_{2}$-fixation ability could be proved by a multidisciplinary approach. All strains were subjected to a nifD-specific PCR amplification. The expected 390 bp amplification product (Stoltzfus et al., 1997) was observed with all strains 
Table 2. Physiological differences between A. doebereinerae sp. nov. isolates and the other Azospirillum species

Data were compiled from Magalhães et al. (1983), Falk et al. (1986), Reinhold et al. (1987), Khammas et al. (1989), Ben Dekhil et al. (1997) and this study. -, Present in $10 \%$ or less of the strains; +, present in $90 \%$ or more of the strains; $\mathrm{d}, 11-89 \%$ of all strains positive; ND, not defined.

\begin{tabular}{|c|c|c|c|c|c|c|c|}
\hline Phenotypic feature & $\begin{array}{c}A . \\
\text { doebereinerae sp. nov. }\end{array}$ & $\begin{array}{c}A . \\
\text { lipoferum }\end{array}$ & $\begin{array}{c}\text { A. } \\
\text { largimobile }\end{array}$ & $\begin{array}{c}\text { A. } \\
\text { brasilense }\end{array}$ & $\begin{array}{c}\text { A. } \\
\text { halopraeferens }\end{array}$ & $\begin{array}{c}\text { A. } \\
\text { irakense }\end{array}$ & $\begin{array}{c}\text { A. } \\
\text { amazonense }\end{array}$ \\
\hline \multicolumn{8}{|l|}{ Carbon utilization with API50 } \\
\hline \multicolumn{8}{|l|}{ CHE and API20 NE (aerobic): } \\
\hline$N$-Acetylglucosamine & - & + & + & - & ND & + & $\mathrm{d}$ \\
\hline D-Glucose & d & + & + & $\mathrm{d}$ & - & + & + \\
\hline Glycerol & + & + & + & + & + & - & - \\
\hline D-Mannitol & + & + & + & - & + & - & - \\
\hline D-Ribose & - & + & + & - & + & d & + \\
\hline D-Sorbitol & + & + & + & - & - & - & - \\
\hline Sucrose & - & - & ND & - & - & + & + \\
\hline \multicolumn{8}{|l|}{ Acid from (API50, anaerobic): } \\
\hline D-Glucose & $\mathrm{d}$ & + & + & - & - & - & - \\
\hline D-Fructose & + & + & + & - & + & - & - \\
\hline Biotin requirement & - & + & - & - & + & - & - \\
\hline Optimal temperature for growth $\left({ }^{\circ} \mathrm{C}\right)$ & 30 & 37 & 28 & 37 & 41 & 33 & 35 \\
\hline Polymorphic cells & + & + & + & - & + & + & + \\
\hline
\end{tabular}

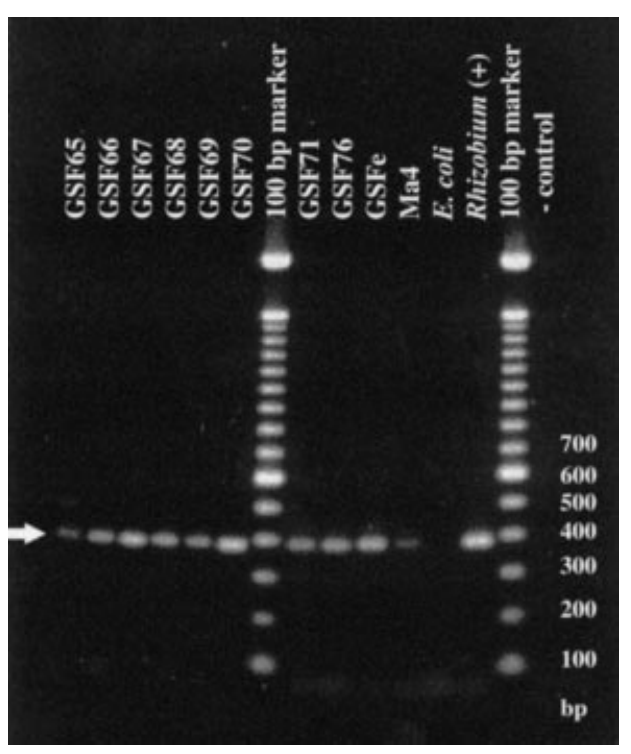

Fig. 3. $P C R$ products derived from specific amplification of the nifD gene.

tested (Fig. 3). In the case of strain GSF71 ${ }^{\mathrm{T}}$, this PCR product was purified and sequenced. The comparison of the resulting sequence with the EMBL database revealed a similarity with the nifD gene of $A$. brasilense of $90 \%$ (Passaglia et al., 1991). The resulting amino acid sequence had $89 \%$ similarity to the nitrogenase molybdenum-iron protein $\alpha$ chain (nitrogenase component I, dinitrogenase, nifD protein) of $A$. brasilense.

The expression of nitrogenase was proved by immunodetection of blotted cell extracts of strains GSF71 ${ }^{\mathrm{T}}$, GSF65, Ma4 and A. brasilense Wa3 (positive control) grown under nitrogen-fixing conditions, using an antiserum against the dinitrogenase reductase of $R$. rubrum and $A$. vinelandii. When $1.5 \mu \mathrm{g}$ total protein of the cell extract was used, the protein A-purified antiserum reacted with a double band of approximately $31-35 \mathrm{kDa}$, if the bacteria were grown under dinitrogen-dependent conditions (Fig. 4). The dinitrogenase reductase of strains GSF71 ${ }^{\mathrm{T}}$, GSF65 and Ma4 was slightly bigger in size than that of $A$. brasilense Wa3 (Hartmann et al., 1986). In the case of halfstrength DYGS medium supplemented with $10 \mathrm{mM}$ $\mathrm{NH}_{4} \mathrm{Cl}$, no protein bands appeared at the $31-35 \mathrm{kDa}$ position after Western blotting analyses, though three very faint bands appeared at the $21-15 \mathrm{kDa}$ position.

The activity of the nitrogenase was investigated by using an acetylene-reduction assay in nitrogen-free semi-solid NFb medium. Strain GSF71 ${ }^{\mathrm{T}}$ was able to reduce acetylene to ethylene with a mean ratio of approximately $100 \mathrm{nmol}$ ethylene per hour per $10^{8}$ cells at $30{ }^{\circ} \mathrm{C}$ without any addition of yeast extract. This amount is comparable with the values of other Azospirillum species (Reinhold et al., 1987; Magalhães et al., 1983).

All these results prove the diazotrophic character of the new $A$. doebereinerae isolates.

\section{Comparison with species belonging to the genus Azospirillum}

The above-mentioned properties of $A$. doebereinerae isolates from Miscanthus matched with the general characteristics of the genus Azospirillum. However, they differed from their nearest relatives in some physiological properties. In contrast to $A$. largimobile and $A$. lipoferum, they were unable to grow with $N$ acetylglucosamine and D-ribose. A. doebereinerae strains did not need biotin supplement as compared to A. lipoferum and $A$. halopraeferens and they grew with D-mannitol and D-sorbitol as sole carbon sources unlike $A$. brasilense. Unlike $A$. halopraeferens, $A$. doebereinerae was able to use D-sorbitol but was unable to use D-ribose (Table 2). The analysis of the $16 \mathrm{~S}$ 


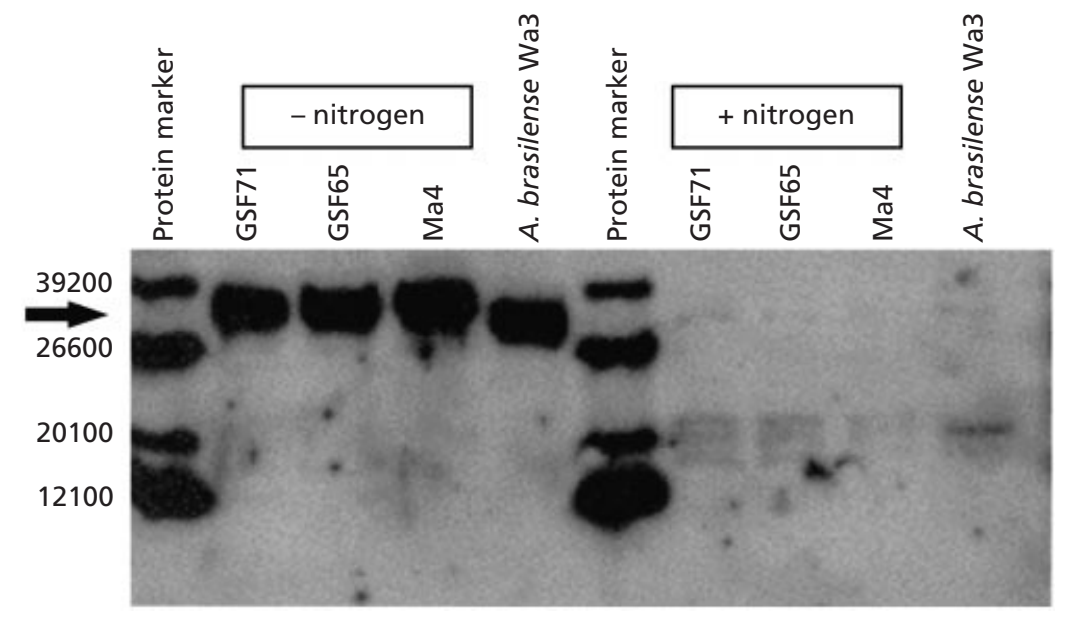

Fig. 4. Immunodetection of the nitrogenase reductase of $A$. doebereinerae sp. nov. strains GSF71 ${ }^{\top}, \mathrm{GSF} 65$ and Ma4 and $A$. brasilense strain Wa3 with a specific polyclonal antiserum against nitrogenase reductase (a gift from Professor P.W. Ludden, Madison, WI, USA). The bacterial cells were grown under nitrogen-fixing conditions in semi-solid NFb medium (nitrogen) and (as the non-nitrogen-fixing control) in media with $10 \mathrm{mM}$ ammonium (+ nitrogen).

rDNA sequence showed that strain GSF71 ${ }^{\mathrm{T}}$ is phylogenetically related to $A$. lipoferum, A. largimobile and A. brasilense (95.9-96.6\% 16S rDNA sequence homology). Sequence differences of more than $3 \%$ are sufficient to allow the proposal of a new species (Stackebrandt \& Goebel, 1994). The group of new isolates from Miscanthus roots appeared homogeneous in their physiological properties and oligonucleotide probing. The application of discriminatory physiological tests and oligonucleotide probes Adoeb94 and Adoeb587 to whole-cell hybridization is appropriate for differentiating and identifying $A$. doebereinerae isolates.

\section{Description of Azospirillum doebereinerae sp. nov.}

Azospirillum doebereinerae (doeb'er.ein.er.ae. N.L. gen. fem. n. doebereinerae of Döbereiner, in honour of Johanna Döbereiner, who isolated and characterized many Azospirillum spp. and other diazotrophic plantassociated bacteria and greatly stimulated the whole field of rhizosphere microbiology, plant-associated nitrogen fixation and plant growth promotion by rootcolonizing diazotrophs).

The bacteria are Gram-negative curved rods or Sshaped, $1.0-1.5 \mu \mathrm{m}$ in width, $2.0-30 \mu \mathrm{m}$ in length (longer cells occur especially in alkaline semi-solid $\mathrm{NFb}$ or JNFb media) and motile with a winding or snake-like movement. A single polar flagellum is observed when the cells are grown in liquid medium. Ageing cells contain intracellular granules. Cells are not encapsulated. The optimum growth temperature is $30^{\circ} \mathrm{C}$ and no growth occurs at $37^{\circ} \mathrm{C}$. The best growth is observed at $\mathrm{pH}$ values between 6.0 and $7 \cdot 0$. The metabolism is of a typical respiratory nature; arabinose, D-fructose, gluconate, glycerol, malate, mannitol and sorbitol can be used as carbon sources. Dinitrogen fixation occurs in microaerobic nitrogenlimited conditions. Microaerobic dinitrogen-fixingdependent growth occurs with malate, sorbitol, mannitol, fructose and glycerol. Catalase, oxidase and urease activities are positive and gelatin is not hydrolysed. $\mathrm{NO}_{3}^{-}$is reduced to $\mathrm{NO}_{2}^{-}$. The $\mathrm{G}+\mathrm{C}$ content of the DNA is $69 \cdot 6 \pm 3 \mathrm{~mol} \%$. The most closely related species, according to $16 \mathrm{~S}$ rRNA sequence data, are Azospirillum lipoferum, Azospirillum largimobile and Azospirillum brasilense. The type strain is GSF71 ${ }^{\mathrm{T}}(=$ DSM $13131^{\mathrm{T}}$ ) and its $\mathrm{G}+\mathrm{C}$ content is $70 \cdot 7 \mathrm{~mol} \%$. The bacterium is associated - as far as is known - with the roots of Miscanthus sinensis cv. 'Giganteus' and Miscanthus sacchariflorus and occurs also in the rhizosphere soil of these plants.

\section{ACKNOWLEDGEMENTS}

We acknowledge the kind support of Dr W. Münzer and $\mathrm{Mr}$ A. Ziegeltrum from the LBP (Freising) for the supply of Miscanthus plant material. We greatly appreciate the scientific leadership and stimulation of Dr Johanna Döbereiner. This work was supported by the Deutsche Forschungsgemeinschaft (DFG grant Ha 1708/5) and the Brazilian/German scientific and technological research cooperation (project BRA ENV 34) and CNPq/PADCT (process no. 620512/94-6).

\section{REFERENCES}

Amann, R. I., Krummholz, L. \& Stahl, D. A. (1990). Fluorescentoligonucleotide probing of whole cells for determinative, phylogenetic and environmental studies in microbiology. $J$ Bacteriol 172, 762-770.

Amann, R. I., Ludwig, W. \& Schleifer, K.-H. (1995). Phylogenetic identification and in situ detection of individual microbial cells without cultivation. Microbiol Rev 59, 143-169.

Baldani, V. L. D., Olivares, F. \& Döbereiner, J. (1995). Selection of Herbaspirillum spp. strains associated with rice seedlings amended with ${ }^{15} \mathrm{~N}$-labelled fertilizer. In International Symposium on Sustainable Agriculture for the Tropics - the Role of Nitrogen Fixation, pp. 202-203. Edited by R. M. Boddey \& A. S. de Resende. Rio de Janeiro: EMBRAPA.

Bally, R., Thomas-Bauzon, D., Heulin, T. \& Balandreau, J. (1983). Determination of the frequent $\mathrm{N}_{2}$-fixing bacteria in a rice rhizosphere. Can J Microbiol 29, 881-887.

Bashan, Y. \& Holguin, G. (1997). Azospirillum - plant relationships: environmental and physiological advances (1990-1996). Can J Microbiol 43, 103-121.

Ben Dekhil, S., Cahill, M., Stackebrandt, E. \& Sly, L. I. (1997). Transfer of Conglomeromonas largomobilis subsp. largomobilis 
to the genus Azospirillum as Azospirillum largomobile comb. nov., and elevation of Conglomeromonas largomobilis subsp. parooensis to the new type species of Conglomeromonas. Syst Appl Microbiol 20, 72-77.

Boddey, R. M. (1987). Methods for quantification of nitrogen fixation associated with gramineae. CRC Crit Rev Plant Sci $\mathbf{6}$, 209-266.

Boddey, R. M., de Oliveira, O. C., Urquiaga, S., Reis, V. M., de Olivares, F. L., Baldani, V. L. D. \& Döbereiner, J. (1995). Biological nitrogen fixation associated with sugar cane and rice: contributions and prospects for improvement. Plant Soil 174, 195-209.

Brosius, J., Dull, T. J., Sleeter, D. D. \& Noller, H. F. (1981). Gene organization and primary structure of a ribosomal RNA operon from E. coli. J Mol Biol 148, 107-127.

Burris, R. H. (1972). Nitrogen fixation - assay methods and techniques. Methods Enzymol 24B, 415-431.

Caceres, E. A. R. (1982). Improved medium for isolation of Azospirillum spp. Appl Environ Microbiol 44, 990-991.

Christian, D. G., Poulton, P. R., Riche, A. B. \& Yates, N. E. (1997). The recovery of ${ }^{15} \mathrm{~N}$-labelled fertilizer applied to Miscanthus $\times$ giganteus. Biomass Bioenergy 12, 21-24.

Christiansen-Weniger, C. \& van Ven, J. A. (1991). Nitrogen fixation by Azospirillum brasilense in soil and the rhizosphere under controlled environmental conditions. Biol Fertil Soils 12, $100-106$.

Döbereiner, J. (1980). Forage grasses and grain crops. In Methods for Evaluation of Biological Nitrogen Fixation, pp. 535-555. Edited by J. F. J. Bergersen. Chichester: Wiley.

Döbereiner, J. (1983). Ten years of Azospirillum. In Azospirillum II: Genetics, Physiology, Ecology, pp. 9-23. Edited by W. Klingmüller. Basel: Birkhäuser.

Döbereiner, J. (1995). Isolation and identification of aerobic nitrogen fixing bacteria from soil and plants. In Methods in Applied Soil Microbiology and Biochemistry, pp. 134-141. Edited by K. Alef \& P. Nannipieri. London: Academic Press.

Döbereiner, J., Marriel, I. E. \& Nery, M. (1976). Ecological distribution of Spirillum lipoferum Beijerinck. Can J Microbiol 22, 1464-1474.

Falk, E. C., Döbereiner, J., Johnson, J. L. \& Krieg, N. R. (1985). Deoxyribonucleic acid homology of Azospirillum amazonense Magalhães et al. 1984 and emendation of the description of the genus Azospirillum. Int J Syst Bacteriol 35, 117-118.

Favinger, J., Stadtwald, R. \& Gest, H. (1989). Rhodospirillum centenum sp. nov., a thermotolerant cyst-forming anoxygenic photosynthetic bacterium. Antonie Leeuwenhoek 55, 291-296.

Giller, K. E., Wani, S. P. \& Day, J. M. (1986). Use of isotope dilution to measure nitrogen fixation associated with the roots of sorghum and millet genotypes. Plant Soil 90, 255-263.

Gunarto, L., Adachi, K. \& Senboku, T. (1999). Isolation and selection of indigenous Azospirillum spp. from a subtropical island, and effect of inoculation on growth of lowland rice under several levels of N application. Biol Fertil Soils 28, 129-136.

Harlow, E. \& Lane, D. (1988). Antibodies: a Laboratory Manual. Cold Spring Harbor, NY : Cold Spring Harbor Laboratory.

Hartley, W. (1958). Studies on the origin, evolution, and distribution of Gramineae 1. The tribe Andopogoneae. Austr $J$ Bot 4, 116-128.

Hartmann, A., Fu, H. \& Burris, R. H. (1986). Regulation of nitrogenase activity by ammonium chloride in Azospirillum spp. $J$ Bacteriol 165, 864-870.
Johnson, J. L. (1989). Nucleic acids in bacterial classification. In Bergey's Manual of Systematic Bacteriology. pp. 1608-1609. Edited by J. T. Staley, M. P. Bryant, N. Pfennig \& J. G. Holt. Baltimore: Williams \& Wilkins.

Khammas, K. M., Ageron, E., Grimont, P. A. D. \& Kaiser, P. (1989). Azospirillum irakense sp. nov., a nitrogen-fixing bacterium associated with rice roots and rhizosphere soil. Res Microbiol 140, 679-693.

Kirchhof, G., Reis, V. M., Baldani, J. I., Eckert, B., Döbereiner, J. \& Hartmann, A. (1997a). Occurrence, physiological and molecular analysis of endophytic diazotrophic bacteria in gramineous energy plants. Plant Soil 194, 45-55.

Kirchhof, G., Schloter, M., Aßmus, B. \& Hartmann, A. (1997b). Molecular microbial ecology approaches applied to diazotrophs associated with non-legumes. Soil Biol Biochem 29, 853-862.

Kirchhof, G., Eckert, B., Stoffels, M., Baldani, J. I., Reis, V. M. \& Hartmann, A. (2001). Herbaspirillum frisingense sp. nov., a new nitrogen-fixing bacterial species that occurs in C4-fibre plants. Int J Syst Evol Microbiol 51, 157-168.

Ladha, J. K., So, R. B. \& Watanabe, I. (1987). Composition of Azospirillum species associated with wetland rice plants grown in different soils. Plant Soil 102, 127-129.

Laemmli, U. K. (1970). Cleavage of structural proteins during the assembly of the head of bacteriophage T4. Nature 227, 680-685.

Magalhães, F. M., Baldani, J. I., Souto, S. M., Kuykendall, J. R. \& Döbereiner, J. (1983). A new acid tolerant Azospirillum species. Ann Acad Bras Cienc 55, 417-430.

Maidak, B. L., Larsen, N., McCaughey, M. J., Overbeek, R., Olsen, G. J., Fogel, K., Blandy, J. \& Woese, C. R. (1994). The ribosomal database project. Nucleic Acids Res 22, 3485-3487.

Malik, K. A. (1988). A new freeze-drying method for the preservation of nitrogen-fixing and other fragile bacteria. $J$ Microbiol Methods 8, 259-271.

Malik, K. A. \& Schlegel, H. G. (1980). Enrichment and isolation of new nitrogen-fixing hydrogen bacteria. FEMS Microbiol Lett $\mathbf{8}$, 101-104.

Manz, W., Amann, R.-I., Ludwig, W., Wagner, M. \& Schleifer, K.-H. (1992). Phylogenetic oligodeoxynucleotide probes for the major subclasses of Proteobacteria: problems and solutions. Syst Appl Microbiol 15, 593-600.

Marchesi, J. R., Sato, T., Weightman, A. J., Martin, T. A., Fry, J. C., Hiom, S. J. \& Wade, W. G. (1998). Design and evaluation of useful bacterium-specific PCR primers that amplify genes coding for bacterial 16S rDNA. Appl Environ Microbiol 64, 795-799.

Okon, Y. (1985). Azospirillum as a potential inoculant for agriculture. Trends Biotechnol 3, 223-228.

Owen, R. J. \& Lapage, S. P. (1976). The thermal denaturation of partly purified bacterial deoxyribonucleic acid and its taxonomic applications. J Appl Bacteriol 41, 335-340.

Passaglia, L. M., Nunes, C. P., Zaha, A. \& Schrank, I. S. (1991). The nifHDK operon in the free-living nitrogen-fixing bacteria Azospirillum brasilense sequentially comprises genes $H, D, K$, an 353 bp orf and gene Y. Braz J Med Biol Res 24, 649-675.

Reinhold, B., Hurek, T., Fendrik, I., Pot, B., Gillis, M., Kersters, K., Thielemans, S. \& De Ley, J. (1987). Azospirillum halopraeferens sp. nov., a nitrogen-fixing organism associated with roots of Kallar Grass (Leptochloa fusca (L.) Kunth). Int J Syst Bacteriol 37, 43-51.

Rodrigues Neto, J., Malavolta, J. R. \& Victot, O. (1986). Meio simples para isolamento e cultivo de Xanthomonas campestris pv. citri Tipo B. Summa Phytopathol 12, 16. 
Schloter, M., Bode, W. \& Hartmann, A. (1995). Characterization and application of a strain-specific monoclonal antibody against the rhizosphere bacterium Azospirillum brasilense Wa3. Hybridoma 16, 183-187.

Schwarz, H., Liebhard, P., Ehrendorfer, K. \& Ruckenbauer, P. (1994). The effect of fertilization on yield and quality of Miscanthus sinensis 'Giganteus'. Ind Crop Prod 2, 153-159.

Skerman, V. B. D., Sly, L. I. \& Williamson, M. (1983). Conglomeromonas largomobilis gen. nov., sp. nov., a sodium-sensitive, mixed-flagellated organism from freshwater. Int $J$ Syst Bacteriol 33, 300-308.

Sly, L. I. \& Stackebrandt, E. (1999). Description of Skermanella parooensis gen. nov., sp. nov. to accommodate Conglomeromonas largomobilis subsp. parooensis following the transfer of Conglomeromonas largomobilis subsp. largomobilis to the genus Azospirillum. Int J Syst Bacteriol 49, 541-544.

Snaidr, J., Amann, R., Huber, l., Ludwig, W. \& Schleifer, K.-H. (1997). Phylogenetic analysis and in situ identification of bacteria in activated sludge. Appl Environ Microbiol 63, $2884-2896$
Stackebrandt, E. \& Goebel, B. M. (1994). Taxonomic note: a place for DNA-DNA reassociation and 16S rRNA sequence analysis in the present species definition in bacteriology. Int $J$ Syst Bacteriol 44, 846-849.

Stoltzfus, J. R., So, R., Malarvithi, P. P., Ladha, J. K. \& De Bruijn, F. J. (1997). Isolation of endophytic bacteria from rice and assessment of their potential for supplying rice with biologically fixed nitrogen. Plant Soil 194, 25-36.

Tarrand, J. J., Krieg, N. R. \& Döbereiner, J. (1978). A taxonomic study of the Spirillum lipoferum group, with descriptions of a new genus, Azospirillum gen. nov., and two species, Azospirillum lipoferum (Beijerinck) comb. nov. and Azospirillum brasilense sp. nov. Can J Microbiol 24, 967-980.

Wittke, R., Ludwig, W., Peiffer, S. \& Kleiner, D. (1997). Isolation and characterization of Burkholderia norimbergensis sp. nov., a mildly alkaliphilic sulfur oxidizer. Syst Appl Microbiol 20, 549-553.

Yoneyama, T., Muraoka, T., Kim, T. H., Dacaney, E. V. \& Nakanishi, Y. (1997). The natural ${ }^{15} \mathrm{~N}$ abundance of sugar cane and neighboring plants in Brazil, the Philippines and Miyako (Japan). Plant Soil 189, 239-244. 